\title{
Sealed Crawl Spaces with Integrated Whole-House Ventilation in a Cold Climate
}

William Zoeller, James Williamson, and Srikanth Puttagunta

Consortium for Advanced Residential Buildings 


\section{NOTICE}

This report was prepared as an account of work sponsored by an agency of the United States government. Neither the United States government nor any agency thereof, nor any of their employees, subcontractors, or affiliated partners makes any warranty, express or implied, or assumes any legal liability or responsibility for the accuracy, completeness, or usefulness of any information, apparatus, product, or process disclosed, or represents that its use would not infringe privately owned rights. Reference herein to any specific commercial product, process, or service by trade name, trademark, manufacturer, or otherwise does not necessarily constitute or imply its endorsement, recommendation, or favoring by the United States government or any agency thereof. The views and opinions of authors expressed herein do not necessarily state or reflect those of the United States government or any agency thereof.

Available electronically at http://www.osti.gov/bridge

Available for a processing fee to U.S. Department of Energy and its contractors, in paper, from:

U.S. Department of Energy

Office of Scientific and Technical Information

P.O. Box 62

Oak Ridge, TN 37831-0062

phone: 865.576 .8401

fax: 865.576 .5728

email: mailto:reports@adonis.osti.gov

Available for sale to the public, in paper, from:

U.S. Department of Commerce

National Technical Information Service

5285 Port Royal Road

Springfield, VA 22161

phone: 800.553 .6847

fax: 703.605.6900

email: orders@ntis.fedworld.gov

online ordering: http://www.ntis.gov/ordering.htm 


\title{
Sealed Crawl Spaces with Integrated Whole-House Ventilation in a Cold Climate
}

\author{
Prepared for: \\ The National Renewable Energy Laboratory \\ On behalf of the U.S. Department of Energy's Building America Program \\ Office of Energy Efficiency and Renewable Energy \\ 15013 Denver West Parkway \\ Golden, CO 80401 \\ NREL Contract No. DE-AC36-08GO28308 \\ Prepared by: \\ William Zoeller, James Williamson, and Srikanth Puttagunta \\ Consortium for Advanced Residential Buildings \\ 61 Washington Street \\ Norwalk, CT 06854 \\ NREL Technical Monitor: Stacey Rothgeb \\ Prepared under Subcontract No. KNDH-0-40342-05
}

July 2015 
The work presented in this report does not represent performance of any product relative to regulated minimum efficiency requirements.

The laboratory and/or field sites used for this work are not certified rating test facilities. The conditions and methods under which products were characterized for this work differ from standard rating conditions, as described.

Because the methods and conditions differ, the reported results are not comparable to rated product performance and should only be used to estimate performance under the measured conditions. 


\section{Contents}

List of Figures

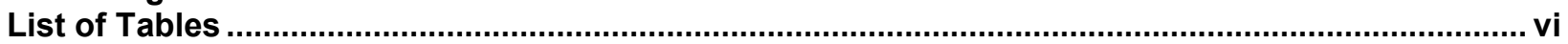

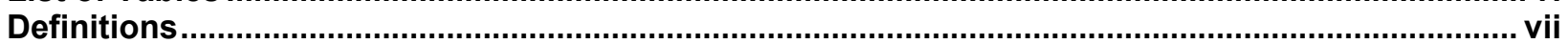

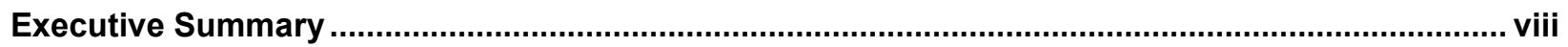

1 Introduction

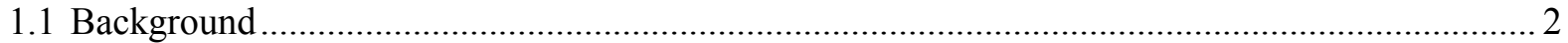

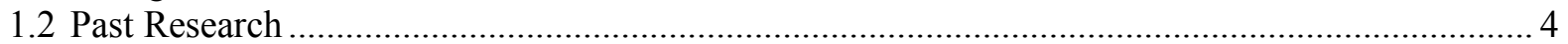

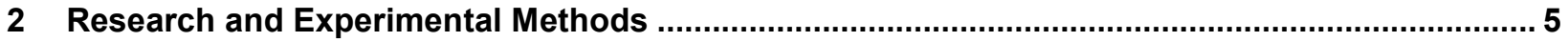

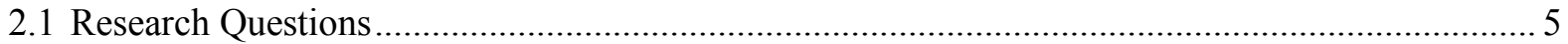

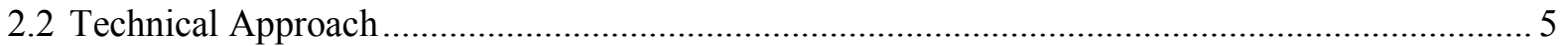

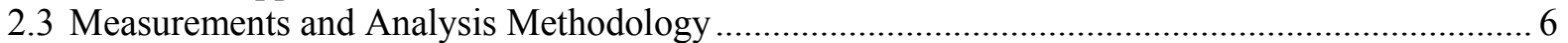

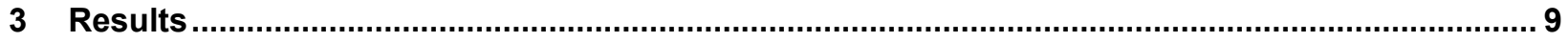

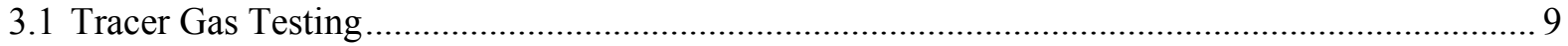

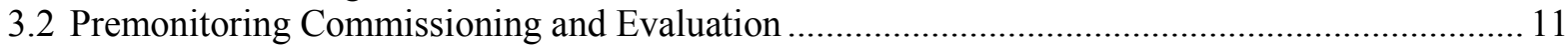

3.3 Long-Term Monitoring of Crawl Space Temperature, Humidity, and Pressure ......................... 12

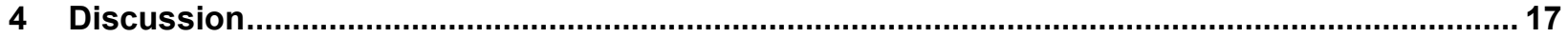

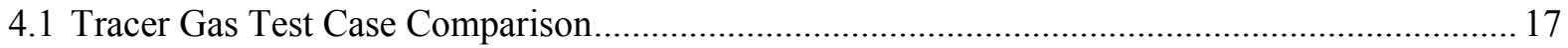

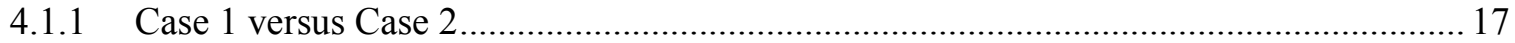

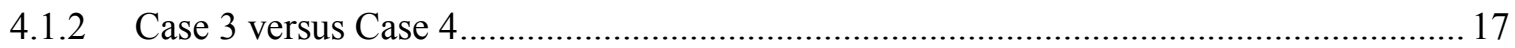

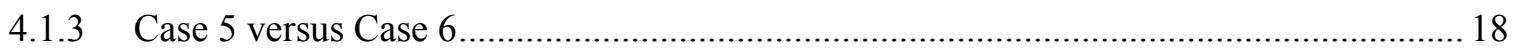

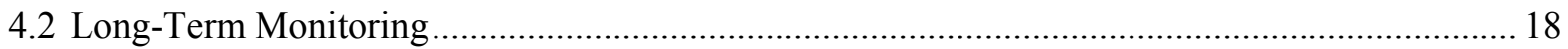

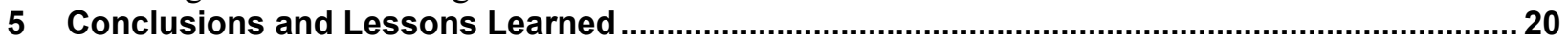

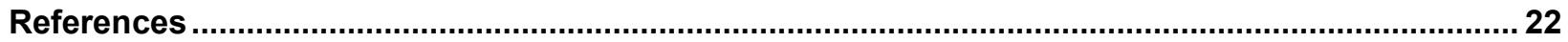

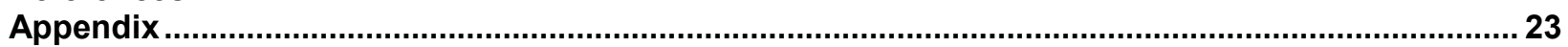




\section{List of Figures}

Figure 1. Ithaca, New York, monitoring site (the two end units were monitored) ............................. 2

Figure 2. Vented crawl spaces often have poor insulation, no vapor control, and unsealed mechanical ductwork. ............................................................................................................ 2

Figure 3. Crawl space insulation (left), vapor barrier (center), and vent fan (right).......................... 3

Figure 4. Case 1, northwest bedroom, $\mathrm{SF}_{6}$ versus time ............................................................... 7

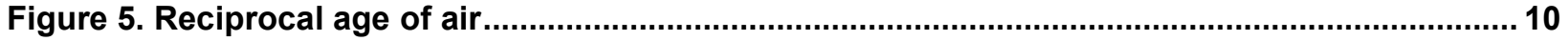

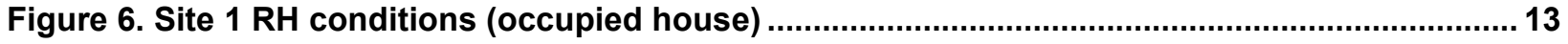

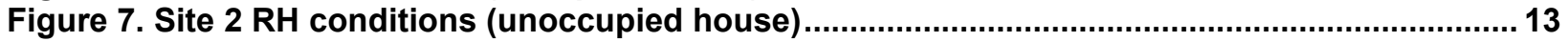

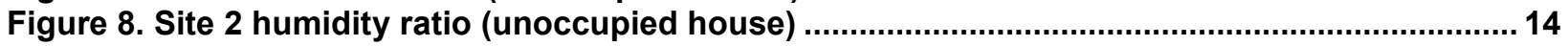

Figure 9. Site 1 condensation potential plot (occupied house) ................................................... 15

Figure 10. Site 2 condensation potential plot (unoccupied house) ................................................... 15

Figure 11. Site 1 histogram and box plot: crawl space pressure with respect to house ................. 16

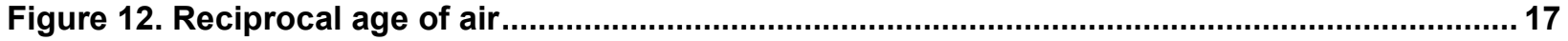

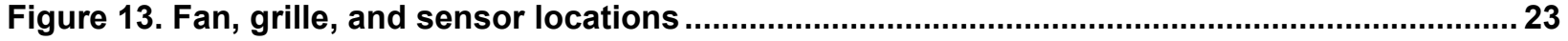

Unless otherwise noted, all figures were created by the CARB team.

\section{List of Tables}

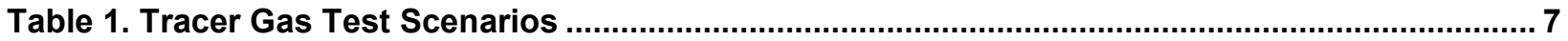

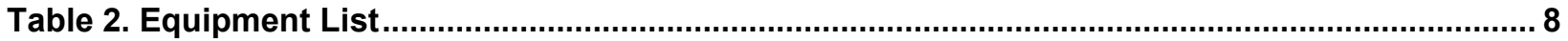

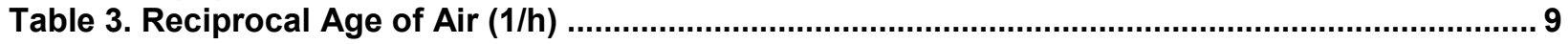

Table 4. Average Temperature Conditions during Tracer Gas Testing ............................................. 10

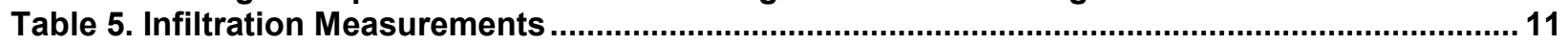

Table 6. Pressure in House with Respect to Crawl Space ............................................................... 11

Table 7. Flow Rates during the Long-Term Monitoring Period ...................................................... 12

Unless otherwise noted, all tables were created by the CARB team. 


\section{Definitions}

ASHRAE

CARB

CFM

IRC

NREL

RAoA

$\mathrm{RH}$

$\mathrm{SF}_{6}$
American Society of Heating, Refrigerating and Air-Conditioning Engineers

Consortium for Advanced Residential Buildings

Cubic feet per minute

International Residential Code

National Renewable Energy Laboratory

Reciprocal Age of Air

Relative Humidity

Sulfur Hexafluoride 


\section{Executive Summary}

One method of crawl space code compliance is to seal and insulate the crawl space, rather than venting to the outdoors. However, codes require mechanical ventilation-either via conditioned supply air from the heating, ventilating, and air-conditioning system or via a continuous exhaust ventilation strategy. Recently, the U.S. Department of Energy's Building America team Consortium for Advanced Residential Buildings (CARB) partnered with Ithaca Neighborhood Housing Services. This partner intended to use unvented crawl spaces in a recent development. CARB was interested in investigating a hybrid ventilation method that includes the exhaust air from the crawl space as a part of an ASHRAE Standard 62.2-compliant whole-house ventilation strategy. Data were collected to investigate the effects of this ventilation on the temperature, relative humidity, and condensation potential within the crawl spaces of two subject homes (one occupied and one unoccupied) in New York State.

This hybrid ventilation method was evaluated through a series of long-term monitoring tests that observed temperature, humidity, and pressure conditions within the home and crawl space. CARB worked with the National Renewable Energy Laboratory to perform multipoint tracer gas testing on six separate ventilation strategies. Varying portions of Standard 62.2 required flow supplied by the crawl space fan and an upstairs bathroom fan. The intents of the tracer gas testing were to (1) identify effective reciprocal age of air (RAoA) (which is equivalent to the air change rate in well-mixed zones) for each strategy, and (2) characterize localized infiltration rates in several areas of the home.

Fresh air distribution patterns remained relatively constant under various combinations of bath and crawl space fan flow. Strategies that used bath fan only, crawl space fan only, and a combination of the two fans always produced slightly higher air change rates at the first floor (19\%-37\% higher with bedroom doors open). No clear correlation emerged that suggests the bathroom fan will have a greater impact on second-floor air exchange rates, or that that the crawl space fan will have a greater impact on first-floor air exchange rates. The data also suggest that running both fans simultaneously did not improve the air exchange rate uniformity between floors.

This research resulted in several key findings:

- Long-term monitoring showed that crawl space moisture conditions exceeded $60 \%$ relative humidity from April through November. During the summer months, condensate had the potential to collect on the vapor barrier at the crawl space floor. In the unoccupied home without air conditioning, the condensation potential totaled 494 hours over the monitoring period (estimated to be equivalent to full-year results). These instances were typically for short durations (about 2 hours), but nine instances of condensation potential lasted 12-24 hours and five instances lasted significantly longer. The longest period lasted 3-1/2 days. The occupied home used window air conditioners, which resulted in significantly fewer instances of condensation potential, at only 49 hours during the monitoring period.

- The crawl space can become positively pressurized with respect to the house when bathroom boosts, kitchen hoods, or dryer vents are used. A rat slab was not installed in 
these homes and the vapor barrier was not continuous (leakage occurred around structural support penetrations and sheet seams, and drainage stones underneath caused wear and tear). Therefore, radon could be pulled into the living space during these worst-case depressurization cases.

- An estimated 30\%-50\% of crawl space fan exhaust air in these "sealed crawl spaces" was entering the crawl space from outdoors.

These initial findings suggest that Section R408.2 of the International Residential Code may warrant a revision, though further validation is needed. A code revision could incorporate the following guidance: An unvented crawl space that meets code compliance via an exhaust fan in the crawl space and a passive vent from the living space should either have air conditioning in the living space or be insulated (along with the continuous vapor barrier) to minimize the potential for summertime condensation in the sealed crawl space. These conclusions were based on results from two homes in the cold-climate region. Further investigation and a larger sample set are needed to verify these findings in a statistically significant manner. 


\section{Introduction}

The U.S. Department of Energy's Building America team Consortium for Advanced Residential Buildings (CARB) has recently been involved in multiple affordable housing projects in climate zones 4,5 , and 6 , where for reasons of economy the chosen building foundation systems were crawl spaces. Aside from overall economy of construction, the circumstances involved in the selection of crawl space foundations were site and project specific and included a high water table, an abundant ledge, and modular construction. The alternative low-cost foundation, slab on grade, is not viable. Recent code changes allow these cost-effective foundation solutions to provide superior energy, moisture control, comfort, and durability by providing for alternative "unvented" crawl spaces. These are in essence mini-basements with the volume being placed within the conditioned enclosure rather than being passively vented to the exterior. The International Residential Code (IRC) does, however, require mechanical ventilation (Section R408.3), which must be accomplished either via conditioned supply air from the heating, ventilating, and air-conditioning system, or via a continuous exhaust ventilation strategy.

Traditional passively vented crawl space foundation construction has not been correlated with positive attributes such as energy efficiency or healthy indoor air quality. The crawl spaces were typically insulated (if at all) with ill-fitting fiberglass batts installed in the floor joist frame cavities; little or no attempt had been made at air-sealing the floor deck. Building codes required that these spaces be provided with vents to the exterior for the purpose of eliminating excess moisture. Theoretically, the air exchange with the exterior is enough to flush the space and control the moisture level within the crawl space. Ironically, measures to control the introduction of moisture into the crawl space (such as a vapor retarder over the earth floor) were not required. Thus, most (or perhaps nearly all) crawl spaces constructed in a typical and code-approved manner have inherent moisture problems that lead to unsatisfactory indoor air quality, elevated moisture levels, and a propensity for mold growth and conditions that are conducive for wooddestroying organisms. Outdoor air introduced into the crawl space keeps the space cold in the winter and may lead to frozen pipes and other negative outcomes. In warmer months, condensation from the warm moist air that contacts the cool walls increases the moisture load and further deteriorates indoor air quality. In all seasons, communication between the vented crawl space and the living space decreases comfort, energy efficiency, and air quality.

As CARB's building partner, Ithaca Neighborhood Housing Services intended to use the unvented crawl space in a recent development. CARB was interested in investigating a hybrid ventilation method that includes the exhaust air from the crawl space as a part of an ASHRAE Standard 62.2-compliant whole-house ventilation strategy. Data were collected to investigate the effects of this ventilation on the temperature, relative humidity $(\mathrm{RH})$, and condensation potential within the crawl spaces of two subject homes (one occupied and one unoccupied) in New York State (Figure 1). 


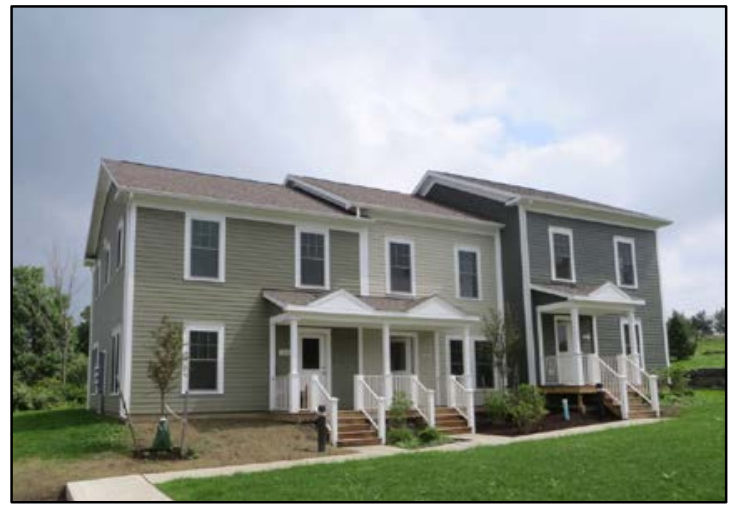

Figure 1. Ithaca, New York, monitoring site (the two end units were monitored)

\subsection{Background}

Typical residential crawl space construction involves placing insulation in the floor framing cavities between the crawl space and the conditioned living space. Most often the unfaced insulation consists of fiberglass batts that are supported with rigid wires between floor joists. Air sealing is usually marginal; the only air barrier is the subfloor, which has no air barrier between the insulation and the crawl space. Moisture management in the form of a vapor retarder on the crawl space floor is often lacking. Passive vents (the number and size of the openings and locations are dictated by code) are intended to flush out excessive moisture, but in practice sometimes introduce moisture-laden air into the space. The resulting performance contributes to unregulated moisture levels, conditions that are conducive to condensation and mold, poor interior space comfort, and nonoptimized energy performance.

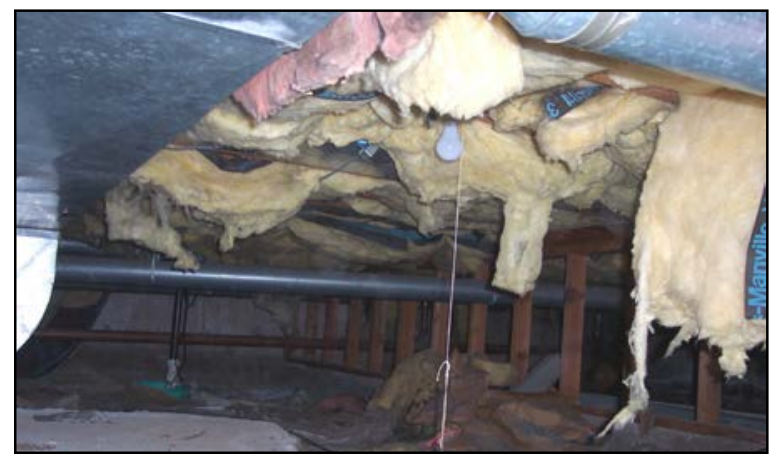

Figure 2. Vented crawl spaces often have poor insulation, no vapor control, and unsealed mechanical ductwork.

Many of these problems have been researched and addressed; eventually code changes were made that allow for unvented crawl spaces in residential construction. First provided for in the 2006 IRC (R408.3 Unvented crawl space), specific requirements to employ this technique were adopted: vapor retarders over earth floors and vertical insulation on the crawl space walls. A mechanical ventilation requirement was also instituted to provide some measure of control over the quality of air within the space. This requirement calls for conditioned air to be supplied to the crawl space or for continuous exhaust ventilation at the rate of $1 \mathrm{CFM} / 50 \mathrm{ft}^{2}$. The specification of a sealed or unvented crawl space is intended to thermally protect the interior space and to 
control moisture and condensation in the crawl space. With these attributes in place, CARB intends to provide:

- An economical foundation system

- Superior energy efficiency and comfort

- High levels of moisture management

- A thermally conditioned (or semiconditioned) space in which to place mechanical systems.

The conditioned supply air method would supply air only when a ducted heating, ventilating, and air-conditioning system is operating in heating, cooling, or fan mode; the amount of air delivered to the crawl space would be equivalent to a minimum of $1 \mathrm{CFM} / 50 \mathrm{ft}^{2}$. This option is not available for homes without ducted heating, ventilating, and air-conditioning systems. Managing and providing the desired amount of exhaust ventilation from the crawl space is theoretically simple. For example, 2 CFM continuous exhaust ventilation would be required in a $1,000-\mathrm{ft}^{2}$ crawl space. This can be accomplished with an electronically commutated motor exhaust fan that draws 10 watts or less. The sealed crawl space and the conditioned occupied space must communicate via a duct, grille, or other method (another requirement of 2006 IRC R408.3), so the 20 CFM being exhausted from the crawl space is intended to be drawn from the occupied space. In essence, this configuration pulls conditioned air from the dwelling through the crawl space and finally to the outside. This continuous exhaust ventilation approach is the subject of this research.

Figure 3 shows three images from one of the monitored crawl spaces. The left image shows the closed-cell spray polyurethane foam (ccSPF) that lined the foundations' walls and rim joist. The ceiling and floor of the crawl space were not insulated. The center image shows the vapor barrier that was applied on the foundation floor. A passive radon pipe was incorporated into the groundwork under the vapor barrier and exhausted through the roof. (CARB recommended that the builder also install a rat slab; however, this was omitted to save construction costs.) A sensor that was used to measure crawl space air temperature and RH is suspended in the center of the space. The right image shows the inline fan that exhausts air from the crawl space to the exterior.
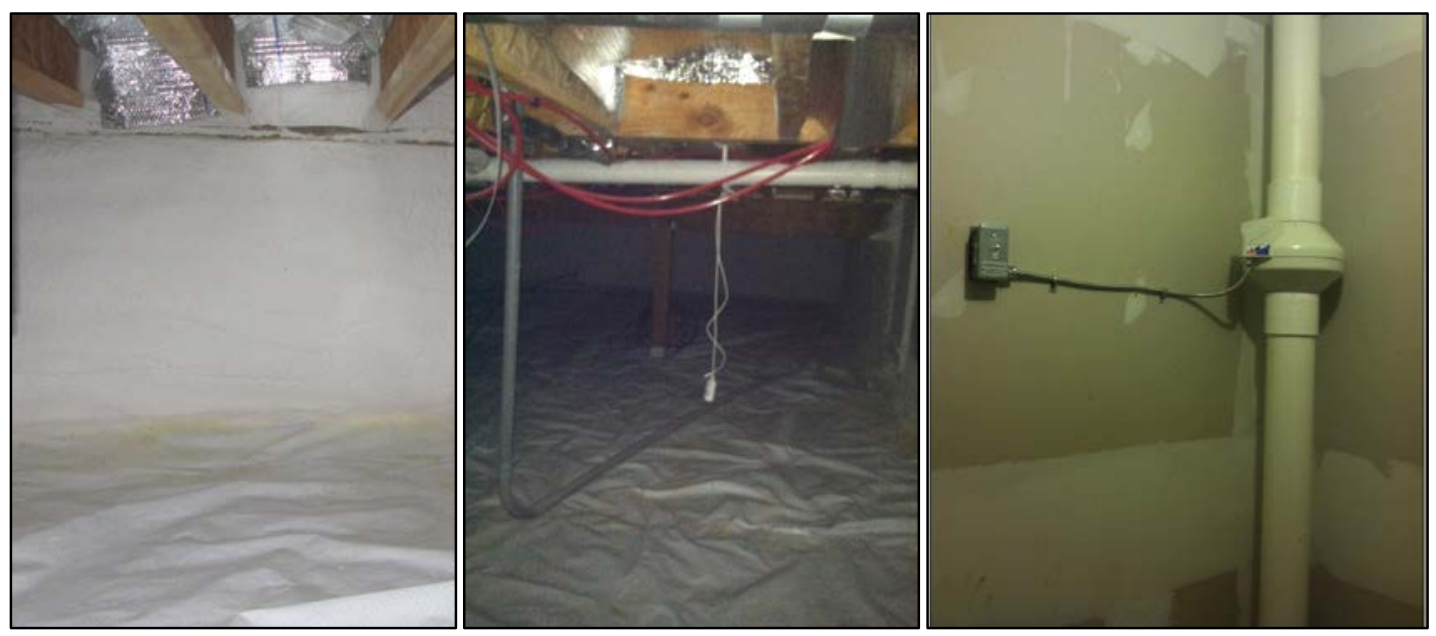

Figure 3. Crawl space insulation (left), vapor barrier (center), and vent fan (right) 


\subsection{Past Research}

The concept of conditioned crawl spaces has been evaluated in the past. Dastur and Davis (2005) monitored temperature and $\mathrm{RH}$ conditions in 12 North Carolina homes with identical floor plans - four vented crawl spaces and eight closed conditioned crawl spaces. Closed crawl spaces demonstrated far better performance under peak load conditions. The sealed crawl space homes used $15 \%-18 \%$ less space conditioning energy than the vented crawl spaces.

Lstiburek (2004) monitored conditioned crawl spaces in two Ohio homes and one New Mexico home over a 12-month period. The Ohio homes actively supplied conditioned air to the crawl spaces, and the New Mexico home used a passive transfer grille between the crawl space and the living space. As expected, the active conditioning method better controlled the conditions; however, active methods are not always necessary in dry climates.

In 2013, Building America recognized researchers with a Top Innovation award for contributions toward the code adoption of unvented conditioned crawl spaces (DOE 2013b). The research that led to the recognition of this innovation has paved the way for its incorporation into building codes and recent widespread adoption among builders (DOE 2013a).

Karagiozis (2005) conducted a field study to compare the energy and moisture performance characteristics of ventilated and sealed crawl spaces in the South. The sealed crawl spaces delivered superior hygric and thermal performance for particular buildings that were investigated in the Southeast. The author used modeling analysis to determine that a sealed crawl space can yield a greater energy benefit if insulation is installed at the floor joists rather than at the perimeter wall. However, the insulated perimeter method showed a slightly higher temperature and enhanced moisture performance.

In this study, CARB specifically researched the method of exhausting conditioned air through the sealed crawl space (and finally to the outside) rather than providing a dedicated supply/return duct in the space. This report provides a multiple-stage monitoring and analysis effort that demonstrates performance in a climate zone 6 home to address a gap of understanding in this method. 


\section{Research and Experimental Methods}

\subsection{Research Questions}

The following research questions were answered by this project.

- In a cold-climate home, how does pulling ventilation air from the dwelling through the sealed crawl space affect the moisture conditions in the crawl space seasonally? Do humidity levels stay within acceptable levels? If not, what are the frequency and duration of these occurrences, and do they return to acceptable levels?

- How does using the sealed crawl space exhaust ventilation as a part of the whole-house ventilation contribute to total fresh air ventilation within the home? Does combining continuous exhaust ventilation from the second-floor bath fan with continuous exhaust from the crawl space improve the fresh air distribution in the home versus exhausting the same amount of air from the bath fan only? From the crawl space only?

\subsection{Technical Approach}

CARB worked with Ithaca Neighborhood Housing Services to design and execute the test homes' exhaust ventilation systems. Instead of the shallow-frost-protected foundations used in Phase I, sealed (unvented) crawl spaces were used for Phase II. CARB worked with the Ithaca Neighborhood Housing Services team to optimize the design of the two ventilation systems (one that served the crawl space and one that served the second-floor bath).

Before the two test homes were substantially completed (but after the thermal enclosures were completed), CARB placed dehumidifiers in the two crawl spaces to expedite the elimination of construction-related moisture and achieve a moisture level that was relatively commensurate with existing homes. (CARB's experience is that construction-related moisture takes about 12 months to dissipate under normal use and circumstances.) The dehumidifiers were used for approximately 2 months and were removed before the summer monitoring period commenced.

When construction was substantially completed, CARB performed diagnostic testing on the homes and commissioned the exhaust ventilation systems to ensure that the design airflows were being achieved. The second-floor bath fan and the crawl space exhaust fan were adjusted to meet ASHRAE Standard 62.2 design ventilation levels using either one fan only or both in tandem.

Before the homes were occupied and the long-term monitoring commenced, the National Renewable Energy Laboratory (NREL) collaborated with CARB to conduct sulfur hexafluoride $\left(\mathrm{SF}_{6}\right)$ tracer gas testing in the unoccupied homes to map the distribution effectiveness of the ventilation systems. Six ventilation scenarios were evaluated to examine variations of the following strategies: both ventilation systems operating simultaneously, the bath fan only, and the crawl space fan only. In all test cases, the total exhaust ventilation CFM was set to conform to the ASHRAE 62.2 minimum requirement for the homes.

After the tracer gas testing was completed, CARB recommissioned the ventilation systems such that the crawl space ventilation fan drew the calculated CFM rate required by code, and the bath fan drew the remaining CFM amount required to meet ASHRAE 62.2. Ultimately, the actual 
ventilation rates were slightly higher than the required rates because the equipment controls imposed limitations.

Onset HOBO data loggers were placed in the homes' crawl spaces and conditioned spaces and programmed to collect ambient temperature and RH data. Exterior weather data were collected simultaneously. The HOBOs were programmed to log data every 15 minutes. The information was collected through three seasons: summer, fall, and winter. The ventilation systems remained in continuous operation throughout the data collection period.

Data were retrieved and analyzed approximately every 3 months to allow researchers to check data quality and begin initial analysis. The analysis determined the interior temperatures and RHs for the entire measurement period within the crawl spaces and the conditioned homes. The results were designed to determine the appropriateness of this hybrid ventilation approach for moisture control in sealed crawl spaces and ventilation distribution effectiveness using exhaustonly ventilation.

\subsection{Measurements and Analysis Methodology}

This study focused on quantifying the effectiveness of six whole-house exhaust-only ventilation variations and investigated how each can provide better fresh air distribution and minimize energy consumption in homes with sealed crawl spaces. With direction from CARB researchers, NREL used a single-tracer, multizone system to perform tests on one home for one week.

NREL researchers installed 2.5-mm (inside diameter) polyethylene tubing in selected rooms through which air samples were drawn every 12 minutes. Air samples were run through a Bruel and Kjaer model 1303 multipoint sampler and model 1302 multigas monitor. At the beginning of each test, researchers introduced a small amount of $\mathrm{SF}_{6}$ into the home and distributed it evenly through all spaces. By analyzing the rates of decay in $\mathrm{SF}_{6}$ concentration, researchers were able to calculate effective air changes in each space; more accurately, researchers could calculate reciprocal age of air $\left(\mathrm{RAoA}, \mathrm{h}^{-1}\right)$ in each space. Although the parts-per-million measurement showed some uncertainty ( $\pm 5 \%$ accuracy) from the gas analyzer, the bias error canceled out in the analysis because the ratio of measurements was compared from the same sensors. Barley et al. (2007) provide further details about this test procedure. Two tests were run per day; the first test typically started around 8 a.m. and the second was initiated around 7 p.m.

Tracer gas testing was performed under six test conditions. Table 1 shows the combinations of bath fan and crawl space fan measured flow rates. The table also includes a corresponding amount of airflow through the transfer grille and whether bedroom doors were left open or closed during the test. Each flow listed was measured with an Alnor 6200 low-flow balometer.

Tracer gas testing was performed to determine the true ventilation rates of the living spaces. Researchers released $\mathrm{SF}_{6}$ tracer gas into the home, used fans to initially mix the gas around the entire home, and recorded the reduction of gas concentration in the air over time. The rate of gas decay in parts per million can reveal the rate that fresh air is diluting the inside space and indicates the air changes per hour. Figure 4 shows a sample $\mathrm{SF}_{6}$ versus time plot from Case 1 to demonstrate the typical exponential decay curves that were observed during testing. 
Table 1. Tracer Gas Test Scenarios

\begin{tabular}{c|c|c|c|c|c}
\hline Case & $\begin{array}{c}\text { Bath Fan } \\
\text { (CFM) }\end{array}$ & $\begin{array}{c}\text { Crawl } \\
\text { Space Fan } \\
\text { (CFM) }\end{array}$ & $\begin{array}{c}\text { Bath and Crawl } \\
\text { Space Fans } \\
\text { (CFM) }\end{array}$ & $\begin{array}{c}\text { Transfer } \\
\text { Grille } \\
\text { (CFM) }\end{array}$ & $\begin{array}{c}\text { Bedroom } \\
\text { Doors }\end{array}$ \\
\hline $\mathbf{1}$ & 13 & 13 & 26 & 8 & Open \\
$\mathbf{2}$ & 13 & 37 & 50 & 20 & Open \\
$\mathbf{3}$ & 40 & 0 & 40 & 0 (taped & Opf) \\
$\mathbf{4}$ & 0 & 54 & 54 & 26 & Open \\
$\mathbf{5}$ & 20 & 28 & 48 & 14 & Open \\
$\mathbf{6}$ & 20 & 28 & 48 & 14 & Closed \\
\hline
\end{tabular}

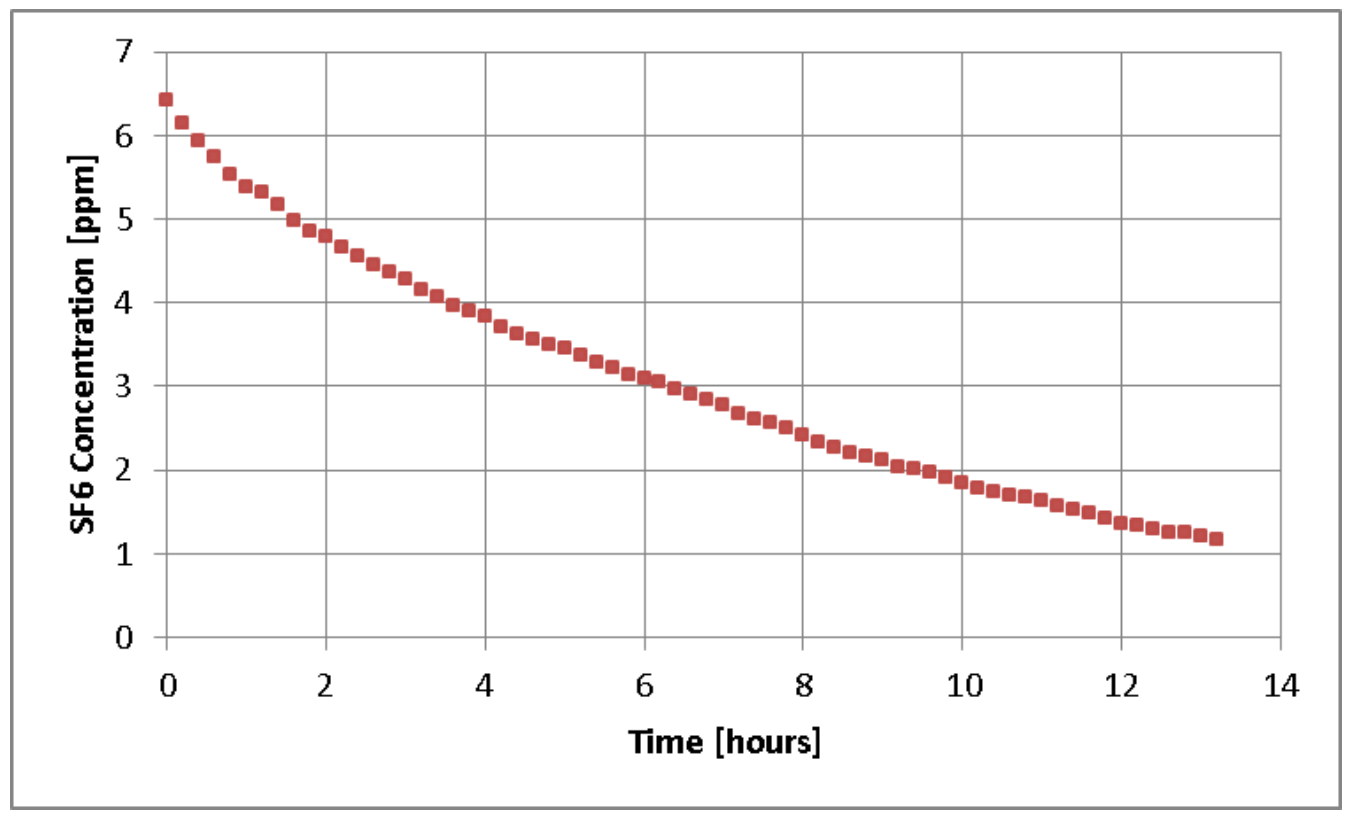

Figure 4. Case 1, northwest bedroom, $\mathrm{SF}_{6}$ versus time

RAoA was calculated by fitting the data set to an exponential decay form shown in Eq. 1 .

$$
\mathrm{C}=\mathrm{Ae}^{-\mathrm{kt}}
$$

Where

$C$ is the $\mathrm{SF}_{6}$ concentration in parts per million predicted at the time $t$.

$A$ is the $\mathrm{SF}_{6}$ concentration at the initial or previous time step.

T is time step in hours, or time that has elapsed between conditions $A$ and $C$

$k$ is a variable in the units $\mathrm{h}^{-1}$ that represents the RAoA. When time is in hours, this variable represents the air changes per hour that are occur between time points $\mathrm{A}$ and $\mathrm{C}$. For this analysis $\mathrm{k}$ was calculated for each time step (approximately every 12 minutes or $1 / 5$ hours) and was averaged for steady parts of the decay curve. 
Onset HOBO U12 data loggers were deployed across several rooms and U23 data loggers were deployed in the crawl space and outdoors to record temperature and RH in 15-minute increments for the duration of the long-term monitoring. Table 2 summarizes the measurements and required sensors and equipment.

Table 2. Equipment List

\begin{tabular}{c|c|c}
\hline Measurement & Equipment Needed & Accuracy \\
\hline $\begin{array}{c}\text { Single Tracer, Multizone } \\
\text { SF6 Testing }\end{array}$ & $\begin{array}{c}\text { Bruel and Kjaer multipoint } \\
\text { sampler with model } 1302 \\
\text { multigas monitor }\end{array}$ & $\begin{array}{c} \pm 5 \% ; 12 \text { hour tests were performed to } \\
\text { obtain accurate calculations of RAoA } \\
\text { in case there was significant } \\
\text { divergence among rooms. } \\
\pm 0.63^{\circ} \mathrm{F} \text { from } 32^{\circ} \text { to } 122^{\circ} \mathrm{F} \pm 2.5 \% \\
\text { from } 10 \% \text { to } 90 \% \mathrm{RH}\end{array}$ \\
$\begin{array}{c}\text { Temperature and RH of } \\
\text { Living Space }\end{array}$ & Onset HOBO U12 \\
$\begin{array}{c}\text { Temperature and RH of } \\
\text { Crawl Space and } \\
\text { Outdoors }\end{array}$ & Onset HOBO U23 & $\begin{array}{c} \pm 0.63^{\circ} \mathrm{F} \text { from } 32^{\circ} \text { to } 122^{\circ} \mathrm{F} \pm 2.5 \% \\
\text { from } 10 \% \text { to } 90 \% \mathrm{RH}\end{array}$ \\
$\begin{array}{c}\text { Airtightness } \\
\text { Ventilation Airflow } \\
\text { Pressure }\end{array}$ & Alnor Low-flow Balometer \\
Veris PXUXX05S & $\begin{array}{c}\text { Minneapolis Blower Door } \\
\text { freading or } 0.15 \mathrm{~Pa}, \text { whichever } \\
\text { is greater }\end{array}$ \\
\hline
\end{tabular}




\section{Results}

\subsection{Tracer Gas Testing}

Only some of the air being exhausted by the crawl space fan was entering the crawl space through the transfer grille. The total flow that was exhausted from the crawl space and the flow through the transfer grille were measured with a low-flow balometer so the fraction of air entering through the grille could be determined. For the cases examined, $48 \%-62 \%$ of total exhaust airflow was measured through the transfer grille. This result, along with the balometer results, may indicate that the transfer grille was undersized. If the area of the transfer grille were increased, air resistance might be reduced between the crawl space and the living space to create a more favorable path for air to be drawn through the grille rather than from other locations.

Potential sources of crawl space exhaust air include seams at the vapor barrier on the crawl space floor, the radon pipe, foundation wall, access hatch, or crawl space ceiling (floor of conditioned space). The exterior foundation walls were spray foamed; however, shared walls between units were not insulated in the crawl space except for the outer 5 feet. Thus, air may leak between the demising walls of the attached units. To provide adequate ventilation, leakage through the crawl space ceiling would be most desired, because stale air is still being exhausted from the living space. However, if air is leaking in from the outside, the ventilation rate is lower than intended and unconditioned air is directly entering the crawl space. These factors increase the potential for moisture, air quality, and comfort problems. Table 3 shows all the reciprocal air changes per hour $(1 / \mathrm{h})$, which were determined through testing. Figure 5 shows a graphical display of the data. As seen for locations of master bedroom and northeast bedroom for Case 6 , the data were too unsteady to pinpoint an exact rate of decay, so the value is presented as a range. See the Appendix for the locations of the exhaust fan, transfer grille, and sensors on a floor plan.

Table 3. Reciprocal Age of Air (1/h)

\begin{tabular}{c|c|c|c|c|c|c}
\hline Case & $\begin{array}{c}\text { Master } \\
\text { Bedroom }\end{array}$ & $\begin{array}{c}\text { Southeast } \\
\text { Bedroom }\end{array}$ & $\begin{array}{c}\text { Northeast } \\
\text { Bedroom }\end{array}$ & Living & $\begin{array}{c}\text { Kitchen- } \\
\text { Dining }\end{array}$ & Entrance \\
\hline Case 1 & 0.12 & 0.13 & 0.12 & 0.17 & 0.17 & 0.18 \\
Case 2 & 0.15 & 0.16 & 0.17 & 0.25 & 0.26 & 0.25 \\
Case 3 & 0.25 & 0.26 & 0.26 & 0.32 & 0.33 & 0.33 \\
Case 4 & 0.13 & 0.14 & 0.14 & 0.19 & 0.21 & 0.19 \\
Case 5 & 0.22 & 0.22 & 0.22 & 0.27 & 0.27 & 0.27 \\
Case 6* & $0.07-0.11$ & 0.11 & $0.07-0.11$ & 0.30 & 0.31 & 0.31 \\
\hline
\end{tabular}

* For the master bedroom and northeast bedroom, the data were too unsteady to pinpoint the exact rate of decay. For analysis purposes, the RAoA is treated as the average of the range. 


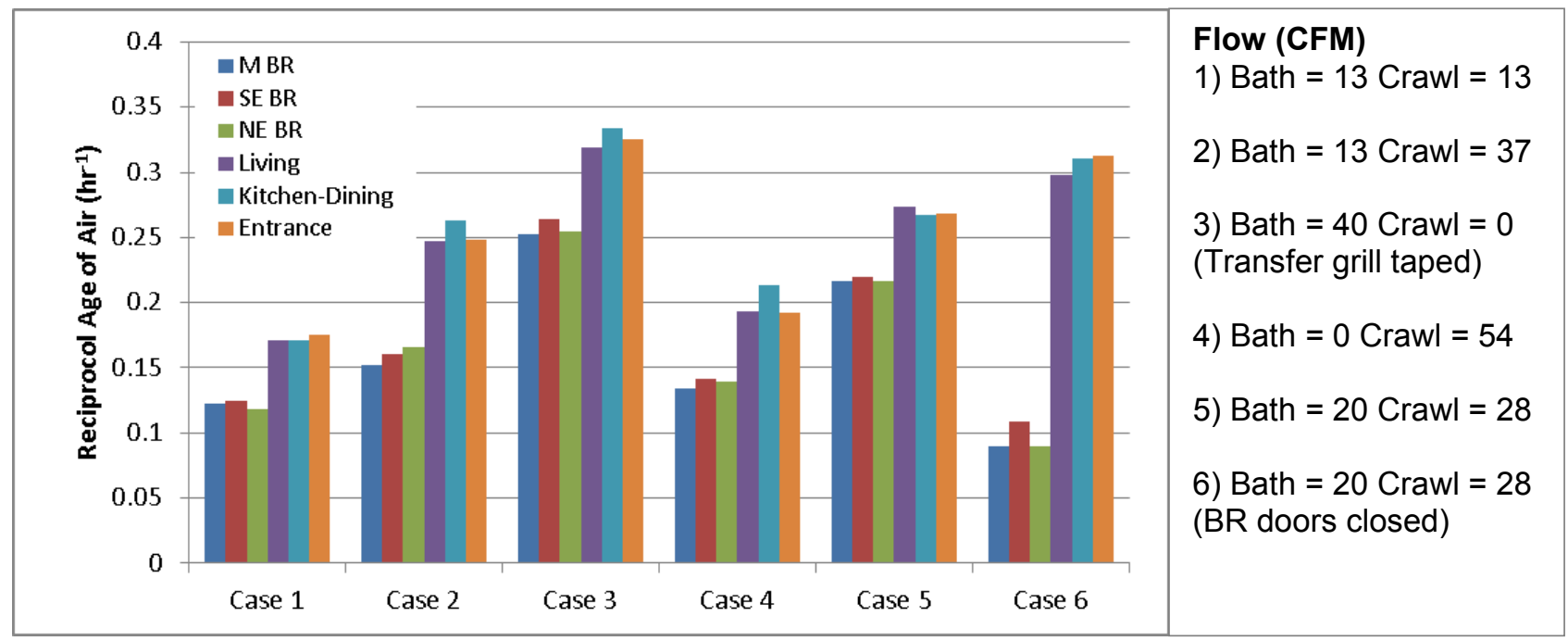

Figure 5. Reciprocal age of air

Temperature difference between indoor and outdoor spaces is a driver of infiltration and should be considered when analyzing RAoA results. Table 4 presents average indoor temperature (separated into first floor and second floor) and outdoor temperature. Second-floor temperatures are typically $0^{\circ}-2^{\circ} \mathrm{F}$ warmer than first-floor temperatures. For the six test cases, outdoor temperatures are $4^{\circ}-20^{\circ} \mathrm{F}$ cooler than indoor temperatures.

Table 4. Average Temperature Conditions during Tracer Gas Testing

\begin{tabular}{c|c|c}
\hline First Floor $\left({ }^{\circ} \mathbf{F}\right)$ & Second Floor $\left({ }^{\circ} \mathbf{F}\right)$ & Outside $\left({ }^{\circ} \mathbf{F}\right)$ \\
\hline 75 & 77 & 71 \\
78 & 80 & 66 \\
79 & 80 & 74 \\
77 & 79 & 61 \\
78 & 78 & 70 \\
76 & 78 & 58 \\
\hline
\end{tabular}

Because $\mathrm{SF}_{6}$ concentrations were measured in several rooms, air changes per hour could be determined for each room. During all test cases, the first-floor sample point locations (living, kitchen-dining, and entrance) had higher air change rates than the second-floor sample point locations (master bedroom, southeast bedroom, and northeast bedroom). This suggests that more of the home's total exhaust air was being replaced by outdoor air as it entered at the first floor. In several cases peak RAoA occurred around the kitchen. The kitchen exhaust (which was off during testing) might have created a low resistance pathway for air to reenter the house because the backdraft did not provide a perfect seal. On the first floor, a bathroom/laundry room was also directly attached to the kitchen. This may have provided additional leakage pathways through the bathroom vent and dryer vent (these were off during testing). Also, the first floor had two doors to the exterior that may have been sources of makeup air during the depressurized conditions. Lastly, stack effect could increase the RAoA in the first-floor rooms than in the second-floor rooms. 


\subsection{Premonitoring Commissioning and Evaluation}

Before the long-term monitoring began, CARB performed extensive commissioning and evaluation on the ventilation system. This process involved testing infiltration rates, crawl space vent flow rates, and pressure differences under a variety of conditions. A key intention of this evaluation was to determine the amount of air that was leaking in through the crawl space. Table 5 compares flows that were observed during two infiltration tests when the house was depressurized to $50 \mathrm{~Pa}$. Test $\mathrm{A}$ was a standard infiltration test and was used as the baseline for this comparison. Test B was infiltration when the crawl space vent was taped off. Taping the transfer grille restricts air from entering the home through the vent, but air can still leak through the crawl space ceiling.

Table 5. Infiltration Measurements

\begin{tabular}{c|c|c}
\hline Test Conditions & $\begin{array}{c}\text { Flow } \\
\text { (CFM50) }\end{array}$ & $\begin{array}{c}\text { Air Changes } \\
\text { per Hour } \\
\text { (ACH50) }\end{array}$ \\
\hline A. Baseline Infiltration Test & 599 & 3.3 \\
B. Infiltration with Crawl Space Vent Taped & 532 & 3.0 \\
Airflow through Crawl Space Vent during Test A & 139 & N/A \\
\hline
\end{tabular}

Infiltration was reduced when the crawl space vent was taped, which indicates that some air leakage must have originated from outdoor air as it entered the crawl space. During the baseline test, $139 \mathrm{CFM}$ was measured through the vent, and other additional air may have leaked into the home through the crawl space ceiling. When this vent was taped off, infiltration was reduced by only 67 CFM below the baseline.

During the infiltration tests, pressure of the house with respect to the crawl space was also monitored. Pressure conditions that were observed during the two tests are shown in Table 6. A key takeaway from these data is that a substantial pressure difference (-16 Pa) occurred when the crawl space vent was unobstructed. This resistance indicates that some of the air could have been pushed through the crawl space ceiling rather than through the vent. Air that entered the house through the crawl space ceiling under baseline infiltration was calculated to be approximately 75 CFM50 using factors from The Energy Conservatory's "hole added from house to zone" method with the Cox Olson chart (Morin 2011). Using this estimate for airflow through the ceiling and the balometer measured flow through the vent, 214 CFM50 of the total infiltration (36\%) was entering via the crawl space.

Table 6. Pressure in House with Respect to Crawl Space

\begin{tabular}{c|c}
\hline Test & Pressure $(\mathbf{P a})$ \\
\hline Crawl Space Vent Open & -16 \\
Crawl Space Vent Sealed & -33 \\
\hline
\end{tabular}

The commissioning process involved determining the flow rate setting that provided optimal performance and complying with ASHRAE Standard 62.2 requirements. The rates set during continuous testing are shown in Table 7. Larger-than-anticipated crawl space fans were installed at the sites; this presented a challenge for CARB to achieve the low flows that were needed to meet code minimums. During experimental scenario testing, CARB was able to restrict the flow 
by installing a Tamarack Airetrack 62.2 bathroom fan control and further reducing flow by taping off sections of the vent pipe. However, for long-term continuous operation, the tape was removed and left the exhaust flow slightly higher than desired.

The upstairs bathroom fan was controlled with an occupancy sensor so that it ran at lower continuous level and entered a boost mode upon being triggered. The kitchen hood and downstairs bath fan were set to run only when manually operated and the crawl space fan was set to operate continuously.

Table 7. Flow Rates during the Long-Term Monitoring Period

\begin{tabular}{c|c}
\hline Fan & Flow Rate (CFM) \\
\hline Upstairs Bath & $42 / 98$ \\
Kitchen Hood & 95 \\
Downstairs Bath & 77 \\
Crawl Space & 32 \\
\hline
\end{tabular}

The total continuous exhaust flow was set to meet two specifications: ASHRAE 62.2 wholehouse rates and IRC 2012 crawl space ventilation required rates. ASHRAE 62.2-2010 calls for 43.5CFM; the 2013 version calls for 70.5 CFM (no infiltration credit accounted for). The IRC 2012 code mandates that ventilation be 15 CFM for this size crawl space. Continuous fan flow rates were ultimately reduced to the minimum flows (without mechanically restricting airflow with tape as done in the scenario testing).

Once fan flows were determined, CARB performed a test to determine if a worst-case scenario flow configuration could cause the crawl space to become positively pressurized with respect to the house. The worst-case scenario was created by boosting both bath fans, turning on the kitchen range, and closing bedroom doors. The bath and kitchen fans were enough to overpower the crawl space exhaust and create a pressure of $+2.2 \mathrm{~Pa}$ in the crawl space with respect to the house and a 31 CFM flow into the living space.

A hot-wire anemometer was used to measure air velocity in passive radon pipe under two conditions. Air velocity was used to approximate flow based on pipe diameter (4-in. polyvinyl chloride). First, with the fans off, the anemometer indicated a flow of 13 CFM out of the space. With all the fans turned on, 39 CFM of air was being drawn into the pipe (rather than being passively exhausted).

\subsection{Long-Term Monitoring of Crawl Space Temperature, Humidity, and Pressure} A primary goal of the long-term monitoring was to observe moisture levels in the crawl space to determine if they exceeded acceptable conditions. Because a crawl space is not part of the living space and is therefore not designed to satisfy human comfort levels, acceptable is defined for this study as conditions that are not conducive to mold growth and that preserve the structural integrity of the framing lumber. The U.S. Environmental Protection Agency identifies moisture problems that result from high humidity with a threshold of $60 \%$ RH (EPA 2012). Bergman (2010) recommends that framing lumber be kept at a moisture content no higher than 15\%-19\%. For the crawl space temperature conditions in the occupied test home $\left(55^{\circ}-70^{\circ} \mathrm{F}\right)$, this 
equilibrium moisture content condition would not occur until a surrounding air reaches a sustained RH of $80 \%-90 \%$.

Figure 6 shows a plot of RH over time for the crawl space and first floor of the living space at Site 1 . Figure 7 shows the same data for site 2 . In these homes, crawl space RH exceeds the $60 \%$ threshold between approximately May and November. Site 1 used window air conditioners during the summer; Site 2 had no air conditioning.

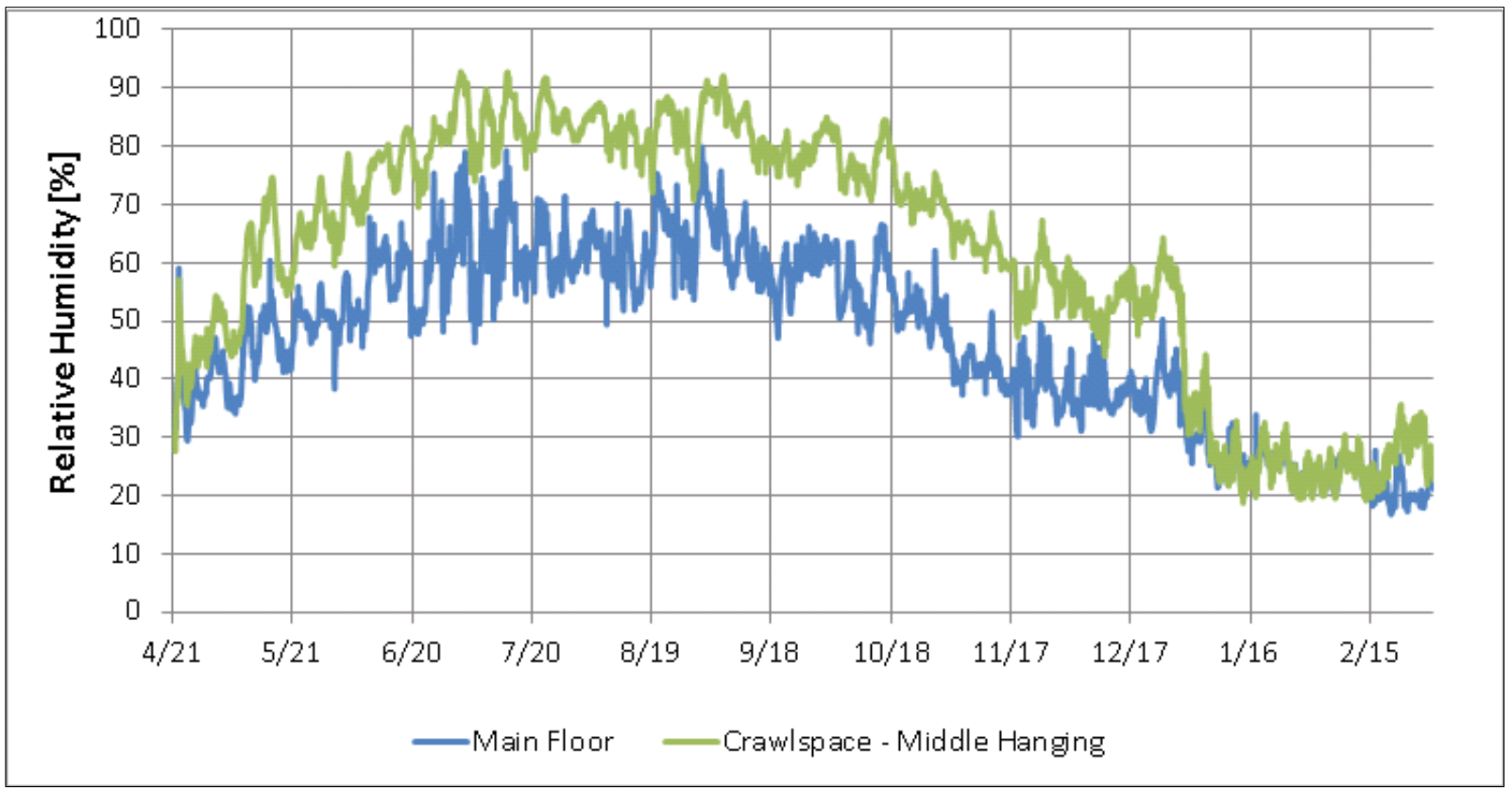

Figure 6. Site 1 RH conditions (occupied house)

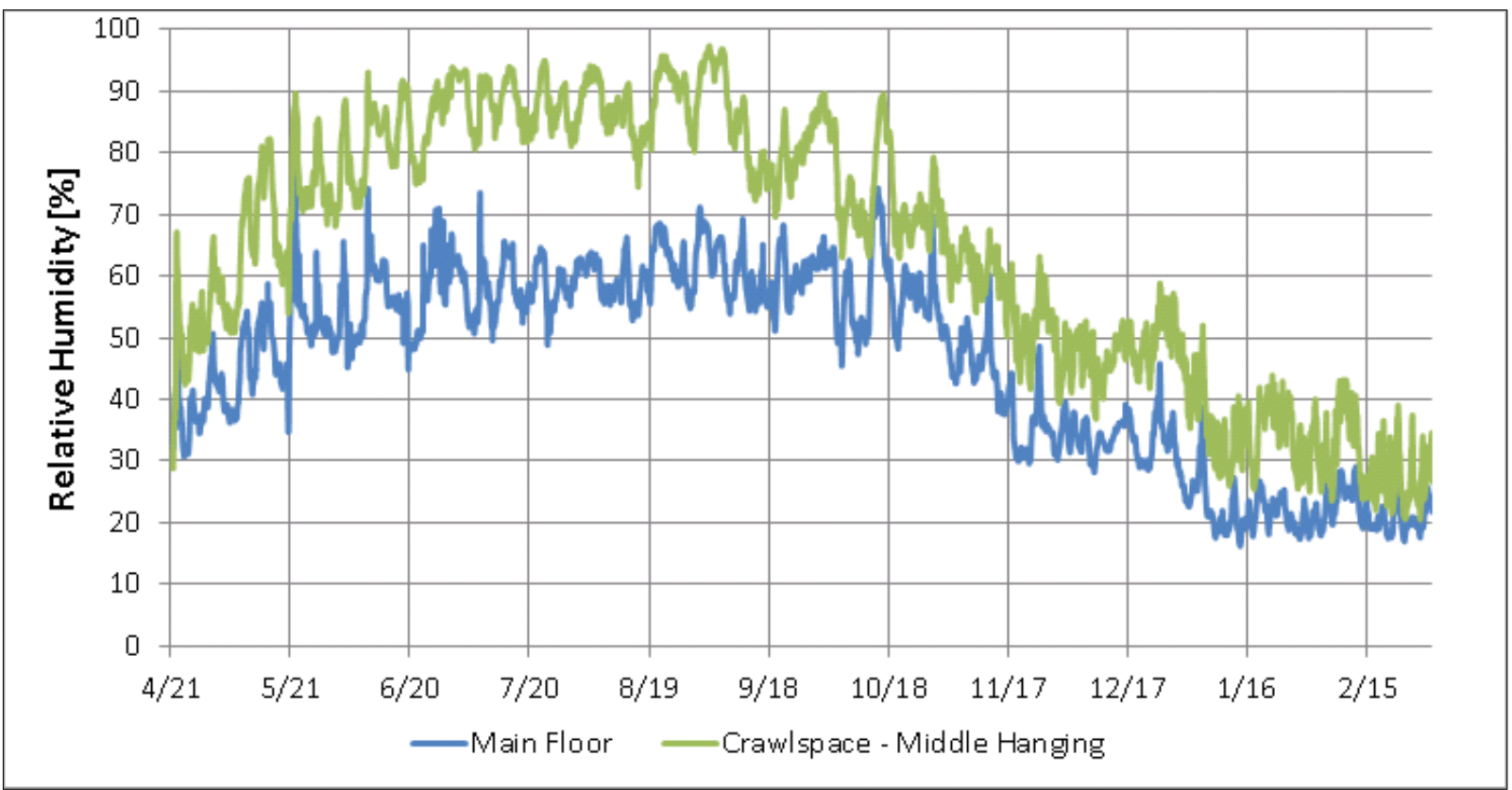

Figure 7. Site 2 RH conditions (unoccupied house) 
The outdoor air humidity ratio was plotted against the crawl space air humidity ratio at site 2 (Figure 8). In general, the indoor humidity ratio closely tracked the outdoor humidity ratio; thus, the spaces were well connected. A closer evaluation revealed that the indoor humidity ratio appeared to trend slightly higher than the outdoor humidity ratio at outdoor conditions higher than $0.01 \mathrm{lbm}$ water/lbm dry air. The opposite was true under drier outdoor air conditions, possibly because construction components (framing, concrete, etc.) provided a moisture buffer.

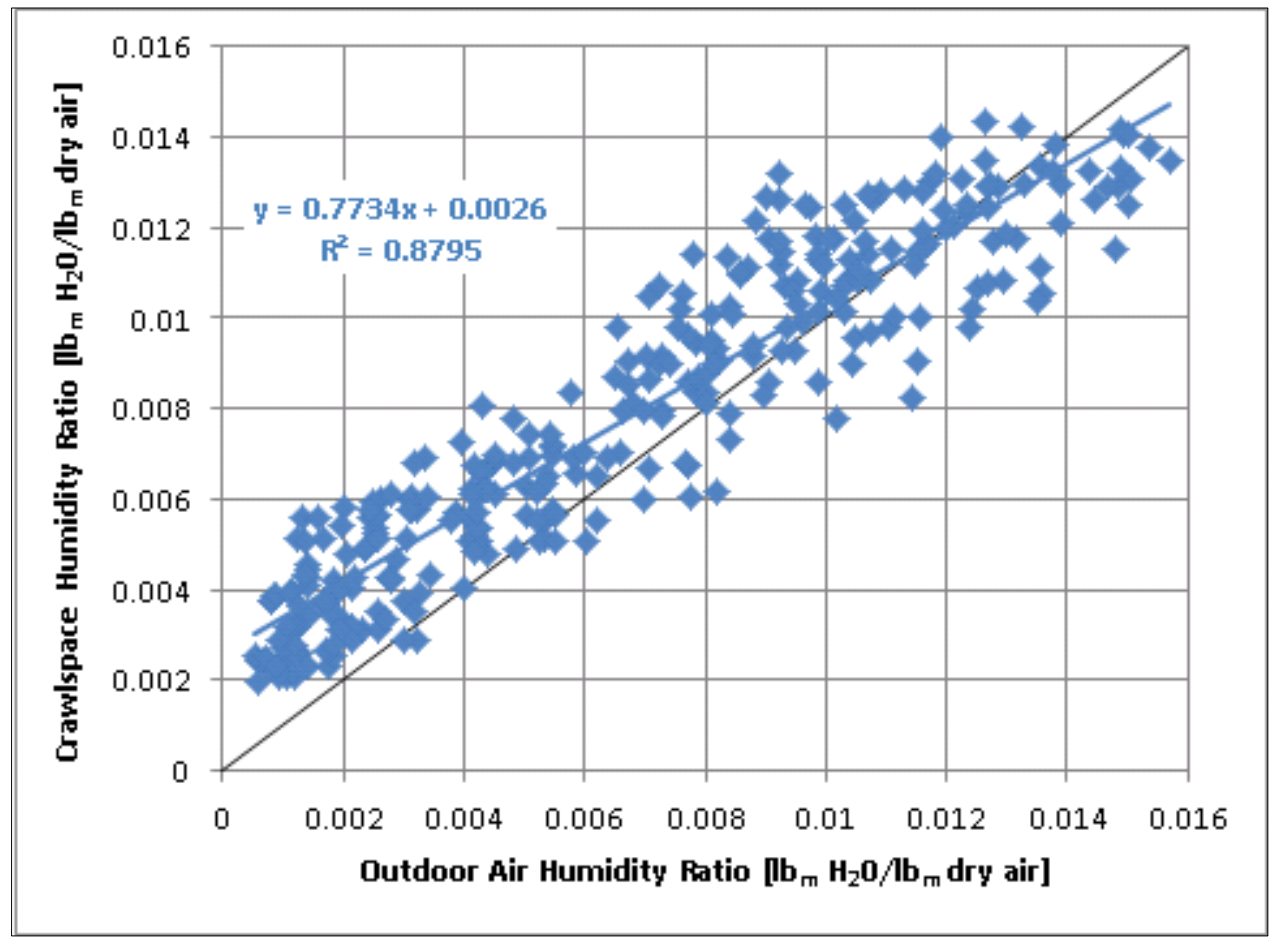

Figure 8. Site 2 humidity ratio (unoccupied house)

Crawl space conditions must be maintained such no condensation can occur. The dew point temperature was calculated based on crawl space air temperaure and $\mathrm{RH}$. A temperature sensor located under the vapor barrier at the floor of crawl space provided an estimate of the coldest surface of the crawl space. Plots with crawl space tarp temperatures and air dew point temperatures are shown in Figure 9 (site 1) and Figure 10 (site 2). The plots show that condensation can occur in both crawl spaces. At site 1 condensation could occur during 44 hours of the monitoring period. At site 2 condensation could occur for 494 hours. These instances were typically for short durations (about 2 hours), but nine instances of condensation potential lasted 12 to 24 hours and five instances lasted significantly longer. The longest period lasted 3-1/2 days. Site visits revealed no previous pooling, staining, or any type of mold or microbial growth. 


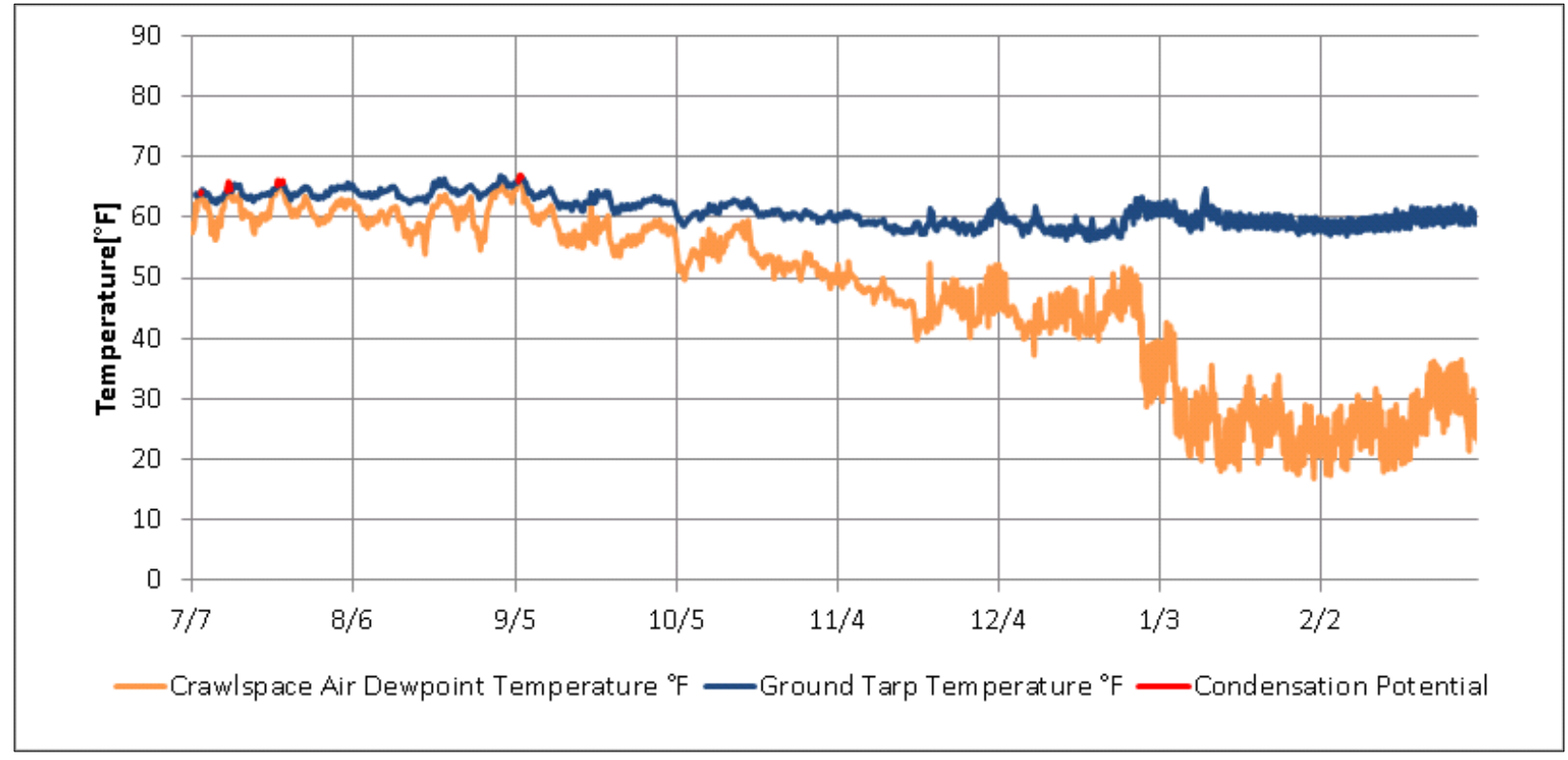

Figure 9. Site 1 condensation potential plot (occupied house)

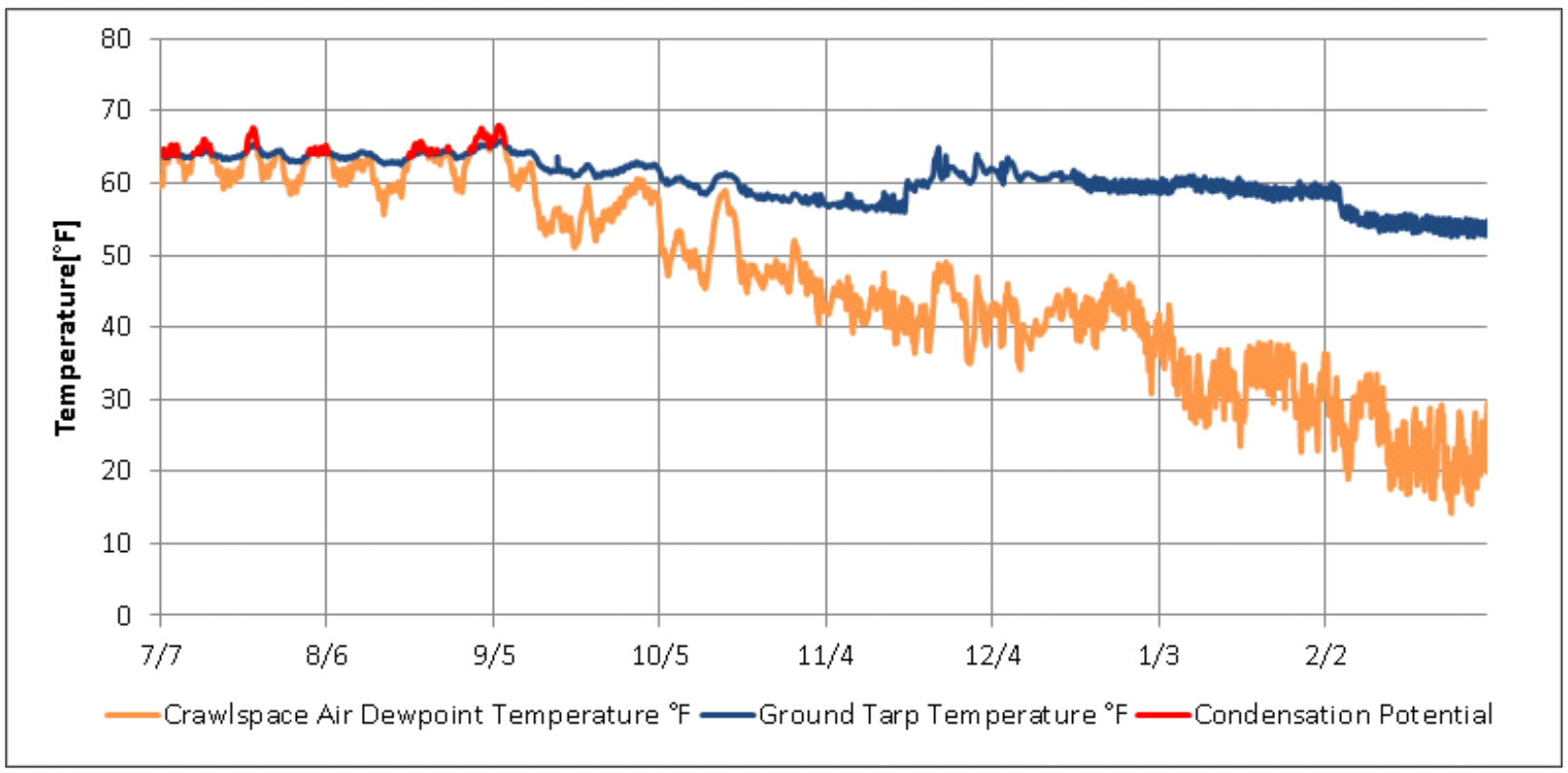

Figure 10. Site 2 condensation potential plot (unoccupied house)

One concern about this ventilation strategy, which was identified during worst-case scenario testing, is that air may occasionally flow from the crawl space to the house. Under normal operation, the crawl space pressure is slightly negative with respect to the living space. However, when the kitchen range hood and bathroom fans are intermittently triggered, the crawl space will likely become positively pressurized relative to the living space. Figure 11 shows a histogram and a box plot that summarize the pressure data of the crawl space with respect to the house from mid-September through mid-December. The box plot displays the following metrics from top to bottom: maximum, third quartile, median, first quartile, minimum. Analysis of the data reveals 
that average crawl space pressure was slightly negative $(-0.23 \mathrm{~Pa})$ with respect to the living space and that it was positive for $24.8 \%$ of the monitoring period.

CARB had originally recommended rat slab foundation floors for these homes. In an effort to cut costs, the builder installed only a sealed-seam polyethylene vapor barrier above the ground. Because the vapor barrier was sectioned together with tape and sealant and laid over jagged drainage stone (punctures in the vapor barrier were noticed in a few locations), the seal between the crawl space and the ground is not airtight. When the crawl space is positively pressurized, radon gases may be pulled into the living space rather than out through the passive radon pipe.

During building infiltration tests, when the house was depressurized to $-50 \mathrm{~Pa}$, pressure differential measurements were made across the vapor barrier. Under these conditions, the pressure under the vapor barrier at site 1 was measured at $5 \mathrm{~Pa}$, and $2 \mathrm{~Pa}$ at site 2 . This pressure difference suggests that air is migrating through seams in the vapor barrier and into the crawl space.
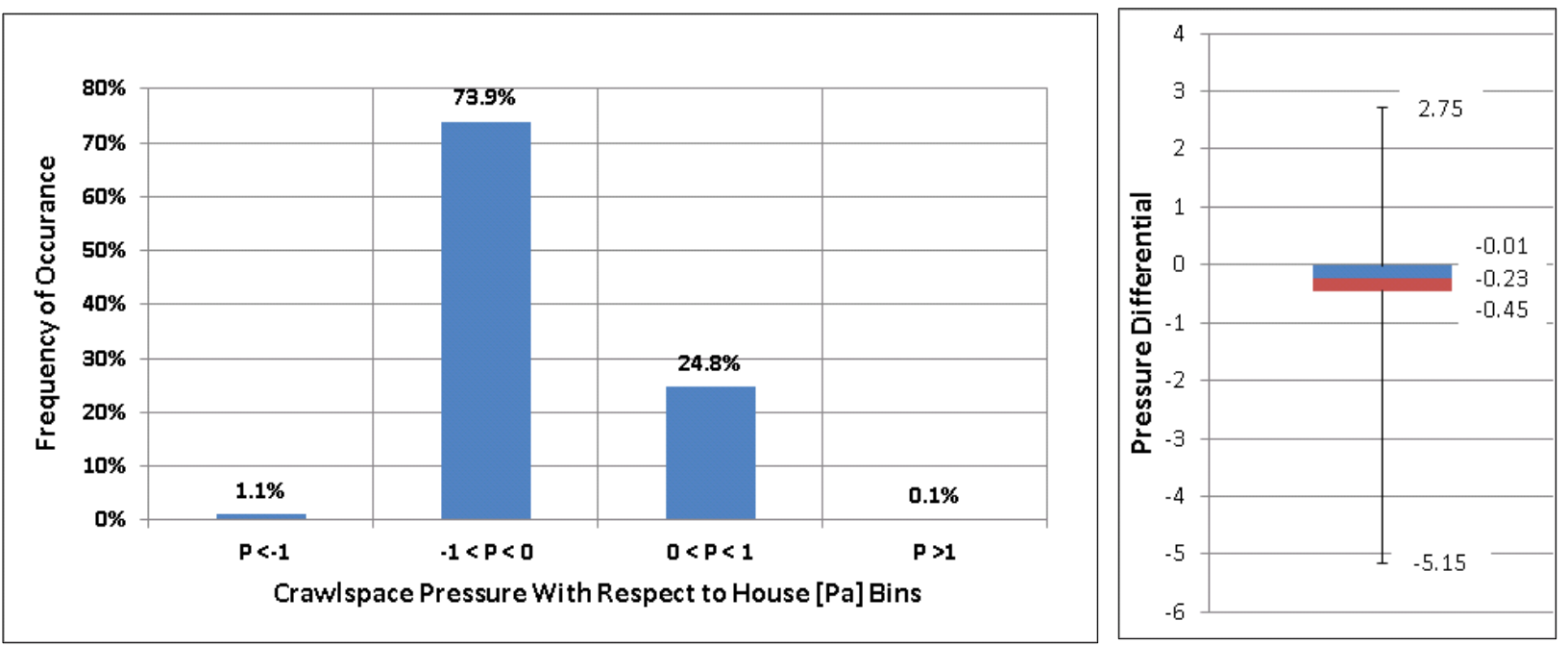

Figure 11. Site 1 histogram and box plot: crawl space pressure with respect to house 


\section{Discussion}

\subsection{Tracer Gas Test Case Comparison}

A useful way to understand the impacts of various flow rate combinations is to compare cases with controlled incremental differences. Section 4.1.1 through Section 4.1.3 analyze the differences observed during three comparisons.

\subsubsection{Case 1 versus Case 2}

The bath fan in each of these cases is set to 13 CFM. For case 1, the crawl space exhaust was also 13 CFM but for case 2 it was elevated to 37 CFM. This gives insight into the impact that increasing the crawl space fan has on total building ventilation effects. As expected, Figure 12 indicates that RAoA rates increased for the first- and second-floor test points; however, the percent increase in RAoA rate is much lower than the percent increase in the total exhaust ventilation rate. For this case, the total indicated ventilation increased from 26 CFM to $50 \mathrm{CFM}$ $(+92 \%)$, but the average RAoA increased from 0.149 to $0.210(+41 \%) .{ }^{1}$ This implies that some of the air being exhausted from the crawl space did not come from the living space.

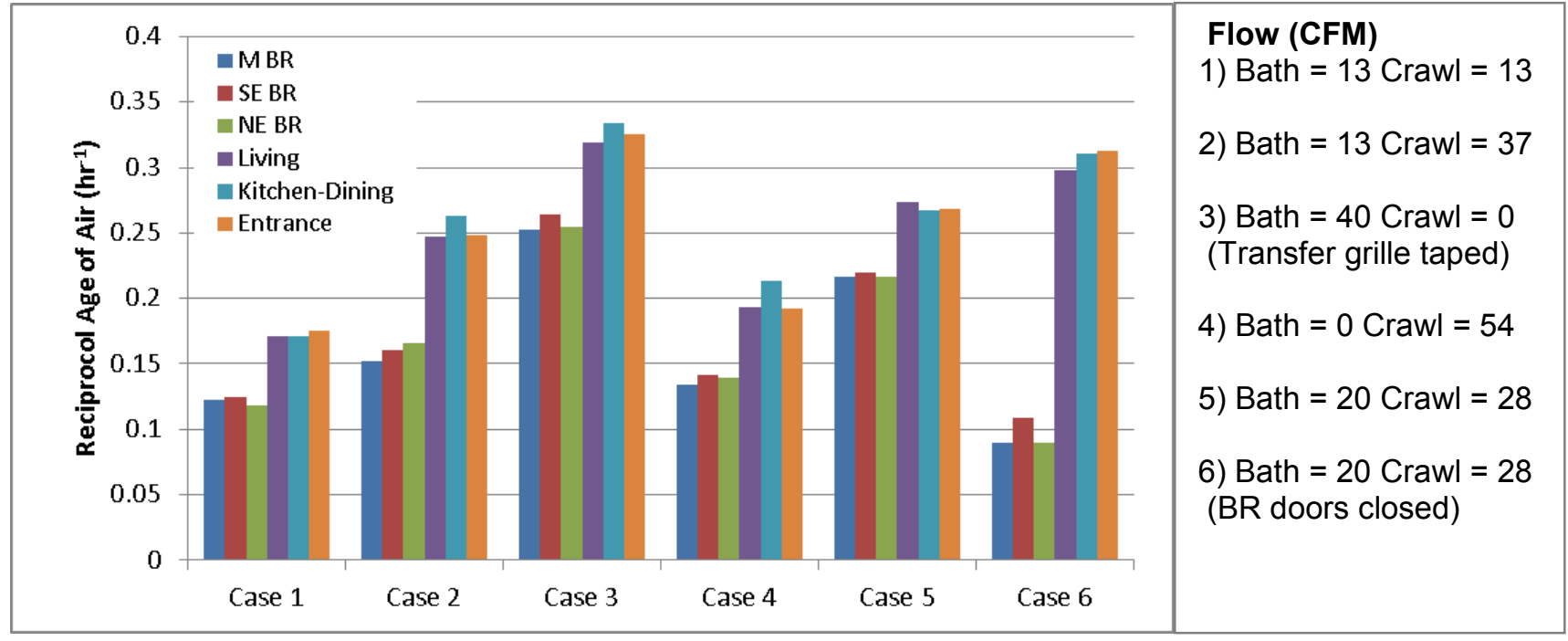

Figure 12. Reciprocal age of air

It is also interesting to examine the rates by which each floor's RAoA rates increased. From case 1 to case 2 , the first-floor rate increased from 0.121 to $0.160(+31 \%)$; the second-floor rates increased from 0.172 to $0.253(+47 \%)$. These increases suggest that an increase in the crawl space ventilation rate had a greater impact on the second floor. Whether or how the location of the passive vent to the crawl space at the base of the stairs impacts this result is unclear.

\subsubsection{Case 3 versus Case 4}

Case 3 used a strategy with only the second-floor bath fan (40 CFM); the crawl space grille was taped off. Case 4 examined a strategy with only the crawl space fan (54 CFM); the bath fan was

\footnotetext{
${ }^{1}$ This simplified average method (volume weighted average of all six test points) assumes that the sample points are representative of the total building rates.
} 
off (the crawl space grille was open in this case). Figure 12 shows that RAoA decreased, even when the fan indicated the flow rate increased from 40 CFM to 54 CFM. This further supports the theory that the crawl space fan may have been sucking air from areas other than the living space. Magnitude or percent change between these two scenarios is difficult to compare without a baseline. However, the outdoor conditions would have had a greater impact on this RAoA rate, because infiltration would have been primarily driven by wind conditions and stack effect. One way to compare these two cases is with an abstract ventilation effectiveness metric: average RAoA rate per measured total exhaust rate (CFM).

For case 3, a rate of $0.0074 \mathrm{RAoA} / \mathrm{CFM}$ occurs and for case 4, $0.0032 \mathrm{RAoA} / \mathrm{CFM}$. These rates indicate that the crawl space fan was only $43 \%$ as effective as the bath fan in diluting indoor air (assuming similar amounts of natural infiltration under each case). Again, some of the airflow measured through the crawl space exhaust pipe apparently did not come from the living space.

\subsubsection{Case 5 versus Case 6}

This comparison is useful for demonstrating the effect that closing the bedroom doors has on RAoA rates and supply air distribution. For both of these cases, the bath fan is set to $20 \mathrm{CFM}$ and the crawl space fan is set to $28 \mathrm{CFM}$. During case 5, the bedroom doors are open and during case 6 , they are closed. Figure 12 shows that bedroom RAoA rates decrease and downstairs RAoA rate slightly increase. However, when doors are closed, the average infiltration rate decreases from 0.246 to 0.211 because the average bedroom RAoA rate decreased from 0.218 to $0.0963(-56 \%)$ and the average downstairs room RAoA rate increased from 0.270 to 0.307 $(+14 \%)$. As expected, less air was exhausted from and supplied to the bedrooms with doors closed. At RAoA rates $<0.010$, bedrooms did not receive enough ventilation when doors were closed. To minimize this effect, doors may need to be left open, an air pathway installed, or an internal circulation system installed to increase ventilation rates during this scenario.

\subsection{Long-Term Monitoring}

The IRC offers the sealed crawl space exhaust strategy as an alternative to delivering conditioned air to the crawl space; make-up air from the living space was assumed to be conditioned. For these climate zone 6 homes, the developer did not install air conditioning (this is not entirely uncommon). Thus, conditions in the crawl space exceed $60 \% \mathrm{RH}$ from May through November. If the air pulled through the space were always conditioned, lower humidity would be expected.

In terms of potential code revisions, if a sealed crawl space in a cold climate is meeting code via an exhaust fan in the crawl space and passive vent from the living space, either the living space must be actively air conditioned or the crawl space floor must be insulated (and a continuous vapor barrier installed) to minimize the potential for summertime condensation in the sealed crawl space.

A crawl space that is occasionally positively pressurized is an undesired result of this ventilation strategy. When bath, kitchen, and dryer ventilation are enough to overpower the crawl space ventilation, air can enter the living space from the crawl space. If mold does develop in the crawl space, spores might be drawn into the living space and result in health problems. Radon gas transport is also a concern. The researchers believe that the alternative sealed crawl space strategy allowed by code (ducted supply air) raises similar concerns and does not mitigate the 
problem. Without a rat slab ground covering, the possibility of radon gases increases and moisture might be drawn into the living space. CARB recommends installing a rat-slab on top of the vapor barrier in any sealed crawl space. 


\section{Conclusions and Lessons Learned}

In a cold-climate home, how does pulling ventilation air from the dwelling through the sealed crawl space affect the moisture conditions in the crawl space seasonally? Do humidity levels stay within acceptable levels? If not, what are the frequency and duration of these occurrences, and do they return to acceptable levels?

Pulling ventilation air from the dwelling to the crawl space did not prevent the humidity from exceeding $60 \% \mathrm{RH}$ from May through November. Outside this period, RH generally remained lower than the $60 \%$ threshold. During brief periods of the peak humidity summer months, condensation may have formed on the crawl space floor's vapor barrier. In the occupied home, the window air conditioners drastically reduced the instances of condensation potential in the crawl spaces compared to the unoccupied unit (from 494 hours to 49 hours). In the unoccupied home, durations of condensation potential were typically short (a few hours), but nine instances of condensation potential lasted 12 to 24 hours and five lasted significantly longer. The longest period lasted 3-1/2 days.

With the mechanical systems configuration used in these homes, the conditions apparently did not perform to the levels that code requirements intend. The code language may need to be adjusted to specify that if air is being exhausted in the sealed crawl space, it should be conditioned air (particularly in cooling applications). Alternatively, the sealed crawl space floor could be insulated to increase the surface temperature to reduce condensation potential. However, either approach introduces an added cost for the developer. More research is required to determine strategies that can optimize humidity control and cost-effectiveness. Potential follow-up research may include:

- Further investigation into the size and location of the passive transfer grille

- Examining strategies for better air sealing crawl spaces in attached multifamily dwellings

- Additional long-term monitoring of the hybrid ventilation method, but only with homes that consistently use air conditioning and humidity control in the living space.

How does using the sealed crawl space exhaust ventilation as a part of the whole-house ventilation contribute to total fresh air distribution ventilation within the home? Does combining continuous exhaust ventilation from the second-floor bath fan with continuous exhaust from the crawl space improve the fresh air distribution in the home versus exhausting the same amount of air from the bath fan only? Does the same configuration improve the fresh air distribution in the home versus exhausting the same amount of air from the crawl space only?

During a whole-house blower door test, about $36 \%$ of the infiltration was entering through the crawl space. This indicates that even a "sealed crawl space" with closed-cell spray polyurethane foam applied to the exterior walls can still have considerable air leakage. This leakage allows a significant part of the air that exhausts from the crawl space to come from areas other than the living space. The result is a much lower-than-intended ventilation rate.

The crawl space can become positively pressurized with respect to the house when bathroom boosts, kitchen hoods, or dryer vents are used. Because rat slabs were not installed in these 
homes and the vapor barriers were not continuous (there was leakage around structural support penetrations, sheet seams, and wear and tear from drainage stones underneath), radon might be pulled into the living space during these worst-case depressurization cases.

Measures to reduce air infiltration at the crawl space include:

- Pouring a rat slab over the ground vapor barrier

- Better air sealing at the exterior entry crawl space hatch and an improved gasket system

- Applying spray foam along the entire party wall.

Fresh air distribution patterns remained relatively constant under various combinations of bath and crawl space fan flow. Strategies that used the bath fan only, the crawl space fan only, and a combination of the two fans always produced slightly higher air change rates at the first floor (19\%-37\% higher with bedroom doors open). No clear correlation emerged that suggests the bathroom fan had a greater impact on second-floor air exchange rates or that that the crawl space fan had a greater impact on first-floor air exchange rates. The data suggest that running both fans simultaneously does not increase the air exchange rate uniformity between floors. 


\section{References}

ANSI/ASHRAE Standard 62.2-2013. Ventilation and Acceptable Indoor Air Quality in LowRise Buildings. 20113 ASHRAE, ISSN 1041-2336.

Barley, D., Anderson, R., Hendron, B., and Hancock, E. 2007. A Test Protocol for Room-toRoom Distribution of Outside Air by Residential Ventilation Systems. Golden, CO: National Renewable Energy Laboratory, NREL/TP-55031548. http://www.nrel.gov/buildings/pdfs/31548.pdf.

Bergman, R. 2010. "Chapter 13: Drying and Control of Moisture Content." Wood Handbook, Washington, DC: U.S. Department of Agriculture. http://www.fpl.fs.fed.us/documnts/fplgtr/fplgtr190/chapter_13.pdf.

Dastur, D., and Davis, B. 2005. "Closed Crawl Spaces Do Double Duty." Home Energy. http://www.advancedenergy.org/portal/crawl_spaces/pdfs/Home\%20Energy\%20January \%202005 low\%20res2.pdf.

DOE. 2013a. "Building America Top Innovations Hall of Fame Profile: Unvented, Conditioned Crawlspaces." Washington, DC: U.S. Department of

Energy. http://energy.gov/sites/prod/files/2014/01/f6/1 1d ba innov unventedconditionedcrawl spaces 011713.pdf.

DOE. 2013b. “Unvented Crawlspaces Code Adoption.” Washington, DC: U.S. Department of Energy, PNNL SA90572. http://energy.gov/sites/prod/files/2014/01/f6/4 3c ba innov unventedcrawlspaces 0117 13.pdf.

EPA. 2012. "Chapter 2: Why and Where Mold Grows.” Mold Course. U.S. Environmental Protection Agency, accessed March 11, 2015. http://www.epa.gov/mold/moldcourse/chapter2.html

Karagiozis, A. 2005. Hygrothermal Performance Study (Experimental \& Modeling). Oak Ridge, TN: Oak Ridge National

Laboratory. http://www.advancedenergy.org/portal/crawl_spaces/pdfs/Hygrothermal\%20Study\% 20-\%202005.pdf.

Lstiburek, J. 2004. Conditioned Crawl Space Construction, Performance and Codes. Westford, MA: Building Science Corporation, accessed June 18, 2015. http://www.buildingscience.com/documents/bareports/ba-0401-conditioned-crawlspaceconstruction-performance-and-codes.

Morin, P. 2011. Zone Pressure Diagnostics (ZPD) for Optimal Air Sealing and Insulation. Minneapolis, MN: The Energy Conservatory. http://www.energyconservatory.com/sites/default/files/documents/ZPD_Basics.pdf. 


\section{Appendix}

First Floor
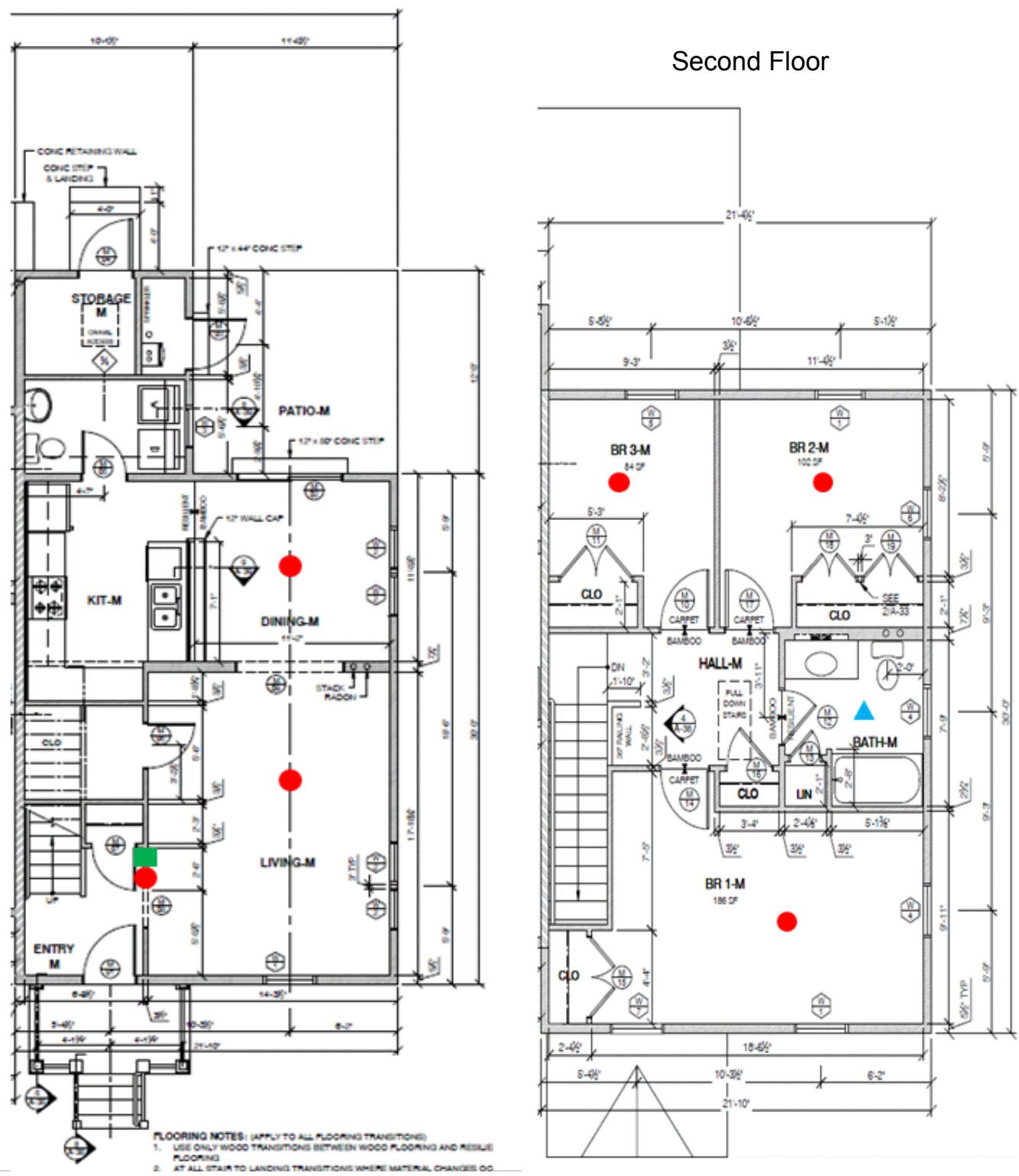

Tracer Gas Sensor Location

Bathroom Exhaust Fan

Transfer Grille to Crawlspace

Figure 13. Fan, grille, and sensor locations 
buildingamerica.gov

\begin{tabular}{l|l} 
u.s. Department of & Energy Efficiency \&
\end{tabular} Nㅡㄹ Renewable Energy 